\title{
INNOVATIVE TECHNOLOGY FOR TESTING OF PROTECTIVE GLOVES SPECIFIC PERFORMANCES
}

\author{
Păun Florin Adrian, \\ National Institute for Research and Development in Mine Safety and Protection to Explosion - INSEMEX \\ Petroşani, City Petroşani, Country Romania, e-mail florin.paun@insemex.ro
}

\begin{abstract}
Părăian Mihaela,
National Institute for Research and Development in Mine Safety and Protection to Explosion - INSEMEX Petroşani, City Petroşani, Country Romania, e-mail mihaela.paraian@insemex.ro
\end{abstract}

Jurca Adrian,

National Institute for Research and Development in Mine Safety and Protection to Explosion - INSEMEX Petroşani, City Petroşani, Country Romania, e-mail adrian.jurca@insemex.ro

\section{Lupu Leonard}

National Institute for Research and Development in Mine Safety and Protection to Explosion - INSEMEX Petroşani, City Petroşani, Country Romania, e-mail leonard.lupur@insemex.ro

\section{Berzan Muntean Florina}

National Institute for Research and Development in Mine Safety and Protection to Explosion - INSEMEX Petroşani, City Petroşani, Country Romania, e-mail florina.muntean@insemex.ro

\begin{abstract}
Presence of hazards along carrying on the work tasks by operators require making use of personal protective equipment, adequate from ensuring protection standpoint. Protecting workers against hazards implies the personal protective equipment to fulfill certain constructional and safety requirements which are very important for the level of protection that should be ensured.This paperwork aims at identifying the constructional and safety requirements for hand protection equipment, as well as the applicable test methods whose results would allow their farther characterization regarding the protection ensured. Innovative solutions are presented, regarding the test stand for determining the blade cut resistance of protective gloves.
\end{abstract}

Key words: personal protective equipment, protective gloves, mechanical risks, laboratory tests, explosive atmosphere

\section{Introduction}

Romania's adhesion to the European Union led to the compulsoriness of aligning its legislation system to the requirements of the European Union's Directives, together with the conventions and recommendations of the International Labour Organization.

The European Union's trend towards a free circulation of any kind of goods is well know and it is legislated through a series of European Directives within the New Approach. Romania, as a member state of the European Union, has taken over in the Romanian legislation framework, a part of the European Directives, especially the ones regarding safety and health at work.

Thus, the Government Decision no. 115/2004 on the essential safety requirements for personal protective equipment and conditions for placing them on the market, modified by HG 809/2005 transposing the Council Directive 89/686/CEE of 21st of December 1989 on harmonizing the member states legislation regarding personal protective equipment, amended by the Directives: 93/68/CEE, 93/95/CEE şi 96/58/EC.

The 89/686/CEE Directive, transposed in our country's legislation by the Government Decisions GD115/2004 and GD809/2005, establishes the essential safety and health requirements applicable to all categories of personal protective equipment (PPE) for the purpose of ensuring protection against the risks for which the PPE had been designed and manufactured. 
Given the role of personal protective equipment in workers protection against hazards, at a national level the aspects concerning ensuring the best conditions in the work process, protection of life, corporal integrity and health of employees and other personnel involved in the operational process, are regulated through the Law of Safety and Health at Work no. 319/2006 and the Methodological Norms for applying the provisions of this law.

In accordance to the Law of Safety and Health at Work no. 319/2006, respectively the Government Decision on the minimum safety and health requirements for use of personal protective equipment by workers at the workplace, the meaning of personal protective equipment is any equipment intended to be worn or held by a worker for protecting him against one or multiple risks which could endanger his safety and health at workplace, as well as any additional element or accessory designed for this purpose.

The protective gloves against mechanical risks are part of the personal protective equipment category, and their role is to ensure protection against at least on of mechanical risks as: abrasion, blade cut and puncture.

Usage of personal protective equipment by workers is mandatory, provided by the Law of Safety and Health at Work no. 319/2006 and thus protective gloves against mechanical risks have to be used within all applications involving presence of hazards of a mechanical nature (abrasion, blade cut and puncture).

Concerning the range of their use, it has to be mentioned that in practice there are certain cases requiring use of protective gloves against mechanical risks by workers developing their activities in areas with explosion danger. In general, in industrial areas processing combustible/flammable substance, in normal working conditions, explosive mixtures of gas, vapor, mists or dusts and air may occur due to technological processes or accidental leakages.

In order to mitigate the explosion risks in this industrial environment usually called "Ex zones", personal protective equipment shall be used of a special construction intended for use in potentially explosive atmospheres, which cannot generate or become sources of energy that could lead to initiating an explosion.

Therefore, the personal protective equipment - protective gloves against mechanical risks used in such "Ex zones" have to fulfill the essential safety requirements regarding explosion hazards by preventing (avoiding) intrinsic sources of ignition of the explosive atmosphere, as for example are the ones of an electrostatic nature.

\section{Methodology of assessment for the hand protection equipment from a standpoint of ensuring protection against hazards}

2.1. Procedures of assessment of personal protective equipment conformity with the requirements in the Directive 89/686/CEE having in view placing it on European market

The goals of the 89/686/CEE Directive are the following:

- to provide the essential safety and health requirements which the personal protective equipment must satisfy to preserve the health and ensure the safety of intended users;

- $\quad$ to ensure free movement of personal protective equipment within the European Community.

At the same time, the 89/686/EEC Directive provides also the assessment procedures for PPE certification, required in order to prove its conformity with the applicable essential safety and health requirements.

For PPE certification, the manufacturer has to provide information in the technical documentation, about the means adopted to ensure conformity of the personal protective equipment with the essential safety and health requirements.

If the manufacturer chooses for ensuring conformity of PPE with this directive to use harmonized European standards, he has to make sure these standards cover all the essential safety and health requirements which are applicable for his product in those foreseeable conditions of use which the product had been intended for.

If the harmonized European standards do not cover all the essential safety and health requirements, the manufacturer has to, additionally to applying these standards, ensure conformity with the essential safety and health requirements that had not been covered by using other relevant technical specifications or other test methods. 
Within this context, it's important to make notice that the personal protective equipment may be placed on the market and made use of only if it is in conformity with all the applicable essential safety and health requirements.

According to the 89/686/CEE Directive (GD 115/2004 and GD 809/2005), the manufacturer or its authorized representative has the obligation of submitting the personal protective equipment mode to one of the following certification procedures:

a) declaration of conformity EC, for PPE of simple design (category I) for which its designer considers the user by himself can assess the level of protection against hazards with gradually shown effects, identifiable in due time and safely;

b) EC type examination, before the series production, accompanied by, at manufacturer's choice, one of the PPE production control procedures as well as by the declaration of conformity, for the PPE of complex design (category III), intended for ensuring protection against hazards leading to death or against hazards which could severely and irreversibly affect health, for which the designer considers the user cannot timely identify immediate effects;

c) EC type examination before the series production, accompanied by the declaration of conformity EC, for those PPE not included in paragraphs a) or b) (category II).

Following PPE certification, the manufacturer or his authorized representative may apply the CE conformity marking which attests PPE conformity with all the provisions in GD no. 115/2004, includin the certification procedures provided in clause 15.

The CE European marking of conformity consists in the capital letters "CE", according to Annex 3 o the Law no. 608/2001, with further modifications and additions. In case a Notified Body intervened in the production control phase, the Notified Body identification number is added too.

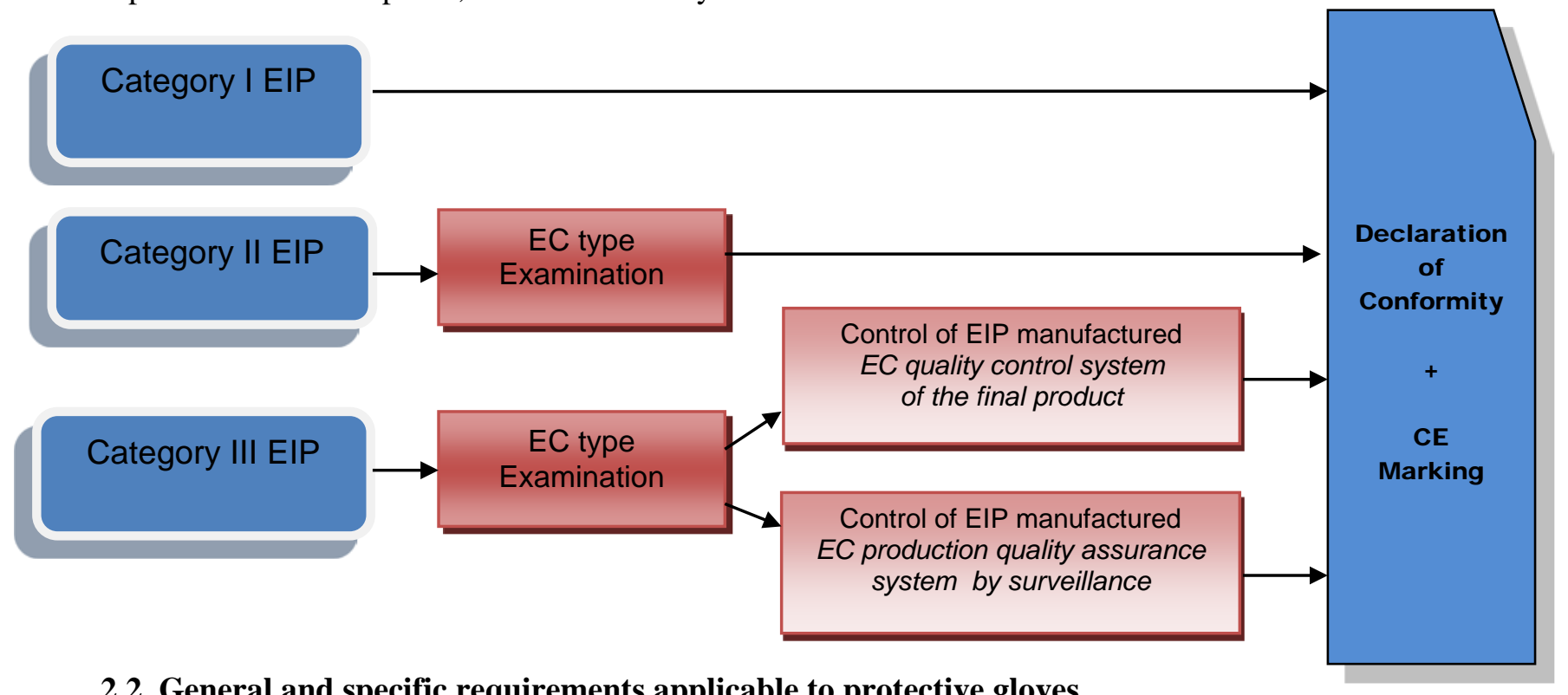

\subsection{General and specific requirements applicable to protective gloves}

In accordance with the standard SR EN 420:2004 „Protective gloves.General requirements and test methods", the protective gloves have to fulfill a range of general requirements, for ensuring protection against hazards regarding glove ergonomics and construction, material resistance against water penetration, innocuousness, comfort and efficiency, and marking and information provided by the manufacturer which are applicable to all protective gloves.

From a construction and design standpoint, the protective gloves have to be designed and manufactured so as to ensure an adequate protection to the highest level possible, in foreseeable use conditions for which they are designed, thus the user can develop a normal activity when exposed to hazards.

If required, the gloves have to be designed to reduce the dressing and/or undressing time to a minimum. If gloves contain seams, their material and resistance have to be such as the general performance doesn't significantly decrease.

The gloves components shall have a certain resistance to water penetration, expressed through one of the performance levels given in the table below: 


\begin{tabular}{|c|c|}
\hline Performance level & $\begin{array}{c}\text { Penetration time, } \\
\text { min }\end{array}$ \\
\hline 1 & 30 \\
\hline 2 & 60 \\
\hline 3 & 120 \\
\hline 4 & 180 \\
\hline
\end{tabular}

The protective gloves have to be designed also so as to ensure protection without harming the wearer when used according to the manufacturer's instructions.

The protective gloves components, the derivative products, the substances included, the seams, the hems and especially the parts in direct contact with the wearer shall not harm his health and hygiene.

In which concerns hand size and dimensions, two main features are considered, the hand circumference and hand length (the distance from the wrist joint to the tip of the middle finger). The protective glove sizes are decided according to the size of the hand which has to wear it. The real size of the glove shall be determined by the manufacturer taking into consideration glove material behavior and intended use.

Dexterity in protective gloves is very important. It's recommended that a protective glove to ensure dexterity as appropriate as possible for the intended use. Glove's dexterity is a function of several factors, as for example the thickness of the glove material, its flexibility and stability of shape.

If necessary, the protective gloves have to hav a water vapor permeability of a minimum of 5 $\mathrm{mg} /\left(\mathrm{cm}^{2} \mathrm{~h}\right)$. If the glove's protective features lower or exclude water vapor permeability, the glove shall be designed such as to diminish the perspiration effects as much as possible.

Additionally to these general requirements, the protective gloves against mechanical risks shall fulfill a series of safety requirements regarding abrasion resistance, blade cut resistance, tear resistance and puncture resistance.

\section{Test stand for determination of blade cut resistance of protective gloves}

The test method for blade cut resistance determination for protective gloves is provided in SR EN 388:2004 „Protective gloves against mechanical risks”.

The test method consists in cutting test samples with a device having a circular blade, moving with an alternate motion under a specified load. Thus, the test sample is submitted to a number of cutting cycles, subsequently recorded and the blade cut resistance index is then calculated.

This blade cut resistance index represents on of the safety parameters of the protective gloves, showing their resistance to cutting by blade. The protective gloves fulfilling this requirement are considered to be adequate from a blade cut resistance standpoint.

The apparatus required for carrying out the test consists in the following:

- a testing machine, moving horizontally, alternative, a rotating circular blade. The stroke is $50 \mathrm{~mm}$ and the blade fully rotates in a sense opposed to the motion sense. The maximum circumferential velocity is $10 \mathrm{~cm} / \mathrm{s}$;

- a weight pressing the blade with a force of $(5 \pm 0,05) \mathrm{N}$;

- the circular blade having the diameter of $(45 \pm 0,5) \mathrm{mm}$, thickness of $(3 \pm 0,5) \mathrm{mm}$ and a cutting angle between $30^{\circ}$ and $35^{\circ}$, made of wolfram steel having a Vickers hardness between 740 and 800 ;

- a conductive rubber support (hardness $80 \pm 3$ DIDC);

- a frame to hold the test sample;

- an automatic cut detection system;

- a cycle number counter, adjusted for tenths of cycles. 
Figure 1. Schematic diagram of the test stand

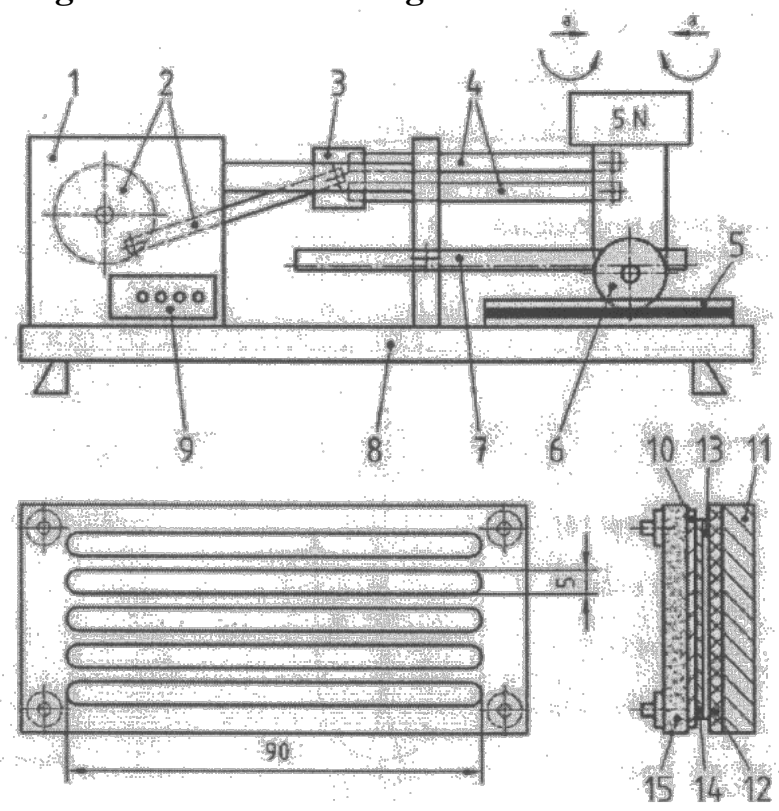

Legend:

1 - motor casing and electronic detection

2 - driving wheel and rod

3 - sliding system

4 - connecting rod

5 - sample support

6 - circular blade

7 - cogged rail

8 - support plate

$$
\begin{aligned}
& 9 \text { - counter } \\
& 10 \text { - test sample } \\
& 11 \text { - insulating support } \\
& 12 \text { - conductive rubber } \\
& 13 \text { - Aluminum foil } \\
& 14 \text { - filter paper } \\
& 15 \text { - upper part } \\
& \text { a - blade alternate motion }
\end{aligned}
$$

Figure 2 shows the test stand for determination of blade cut resistance of protective gloves.

Figure 2. Test stand for determination of blade cut resistance of protective gloves

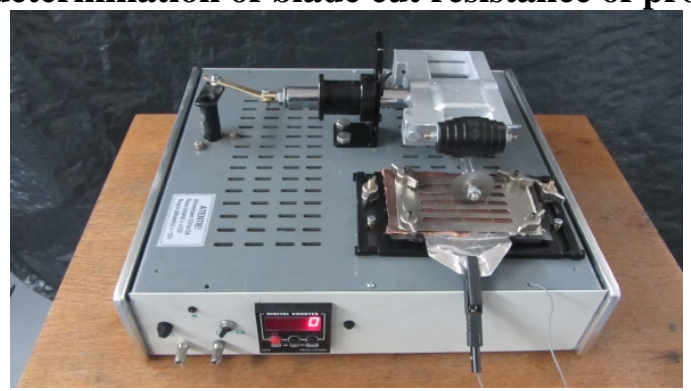

The test stand for determination of blade cut resistance of protective gloves had been carried out as a result of a research project in the National Plan for Research and Development - NUCLEU.

\section{Conclusions}

The protective gloves against mechanical risks have to fulfill essential safety and health requirements applicable, in order to ensure a high level of protection.

Aiming to set out the conformity of protective gloves against mechanical risks with the applicable essential health and safety requirements, laboratory tests are required to establish their properties which influence protection against hazards.

Testing of protective gloves against mechanical risks having in view certification is especially important taking into consideration the existing hazard of mechanical aggressions and the explosion risks that have to be minimized in order to be able to ensure safety of life and health of workers.

The test methods allow ensuring repeatability and reproducibility of tests in various test laboratories, with a great importance since they give a real base of comparison of the test results 
performed in European accredited laboratories, for an accurate assessment of conformity with the essential safety requirements.

In order to have a base of comparison, tests have to be performed according to well defined and accurate methods that would take into account all the factors of influence, thus ensuring correct repeatability and reproducibility.

\section{References}

- Păun F.A.: Proiect Program NUCLEU „Tehnologie inovativă pentru testarea performanțelor specifice echipamentelor pentru protecţia mâinii”, 2014-2015.

- Hotărârea de Guvern nr. 115 din 05 februarie 2004 privind stabilirea cerinţelor esenţiale de securitate ale echipamentelor individuale de protecţie şi a condiţiilor pentru introducerea lor pe piaţă, publicată în Monitorul Oficial, Partea I nr. 166 din 26.02.2004 (Directiva Consiliului 89/686/CEE din 21 decembrie 1989 privind armonizarea legislaţiei statelor Membre referitoare la echipamentul individual de protecţie, amendată prin Directivele 93/68/CEE, 93/95/CEE şi 96/58/EC.);

- Hotărârea nr. 809 din 14 iulie 2005 pentru modificarea Hotărârii de Guvern nr. 115/2004 privind stabilirea cerinţelor esenţiale de securitate ale echipamentelor individuale de protecţie şi a condiţiilor pentru introducerea lor pe piaţă;

- Hotărârea de Guvern nr. 1048/09.08.2006 privind cerinţele minime de securitate şi sănătate pentru utilizarea de către lucrători a echipamentelor individuale de protecţie la locuri de muncă;

- Hotărârea de Guvern nr. 1058/09.08.2006 privind cerinţele minime pentru îmbunătăţirea securităţii şi protecţiei sănătăţii lucrătorilor care pot fi expuşi unui potenţial risc datorat atmosferelor explozive;

- SR EN 420 + A1:2010 Mănuşi de protecţie. Cerinţe generale şi metode de încercare;

- SR EN 388:2004 Mănuşi de protecţie împotriva riscurilor mecanice. 